\title{
POANESTEZINĖS PRIEŽIŪROS, INTENSYVIOSIOS TERAPIJOS IR INTENSYVIOSIOS PRIEŽIŪROS PASLAUGOS
}

\author{
Vilma Traškaitė ${ }^{1}$, Dalia Urbanaitė ${ }^{1}$, Kęstutis Stašaitis ${ }^{2}$, Darius Trepenaitis ${ }^{1}$, Andrius Macas ${ }^{1}$ \\ ${ }^{1}$ Lietuvos sveikatos mokslu universiteto Kauno klinikos, Anesteziologijos klinika, \\ ${ }^{2}$ Lietuvos sveikatos mokslų universiteto Kauno klinikos, Skubiosios medicinos klinika
}

Raktažodžiai: poanestezinè priežiūra, intensyvioji terapija, intensyviosios priežiūros paslauga, intensyviosios priežiūros skyrius.

\begin{abstract}
Santrauka
Poanestezinè priežiūra ir intensyvioji terapija - rutininès paslaugos, teikiamos pasaulio bei Lietuvos ligoninèse, tačiau susidūrus su problema, kai dažnai intensyviosios terapijos skyriai yra perpildomi pacientų, kurie nereikalauja intensyviosios terapijos, o ligoniai po didžiųjų operacijų dažnai būna per sunkios būklès, kad galètų būti gydomi skyriaus palatose, prieita prie tarpinio skyriaus koncepcijos. Intensyviosios priežiūros skyrius- tarsi buferinè zona tarp intensyviosios terapijos ir skyriaus palatos, leidžiančios teikti adekvačias sveikatos priežiūros paslaugas, kurių reikalauja paciento būklè. Šio straipsnio tikslas yra palyginti ir atskirti poanestezinès priežiūros, intensyviosios terapijos ir intensyviosios priežiūros paslaugas. Straipsnyje aptariami intensyviosios priežiūros skyriaus tikslai, kriterijai, darbo organizavimo niuansai remiantis pasaulio ligoniniu praktika.
\end{abstract}

\section{Ivadas}

Pasaulio ligoninèse jau maždaug prieš 25 metus kilo diskusija, kad intensyviosios terapijos skyriai (ITS) yra perpildomi pacientų, kurių būklè nereikalauja intensyviosios terapijos, ir kuriems reikia tiesiog intensyvaus stebèjimo ar slaugos [1]. Anesteziologai iškèlè problemą, kad dažnai pacientai po operacijų, parą praleidę poanestezinès priežiūros palatoje, dar būna per sunkios būklès grižti ị skyrių, kur teikiamos priežiūros ir slaugos paslaugos ne visada pakankamos didesnius poreikius turintiems pacientams. Išryškejjus šiai problemai, pradejjo kurtis tarpiniai intensyviosios priežiūros skyriai (IPS) (angl. high dependency unit, intermediate care unit), kuriuose galèjo būti saugiai gydomi didesnius poreikius turintys pacientai. Nėra nusistovejjusio lietuviškojo šios paslaugos pavadinimo, tačiau atsižvelgiant ị teikiamų paslaugų pobūdị, ši skyrių vadinsime intensyviosios priežiūros skyriumi.

Šio straipsnio tikslas - palyginti ir atskirti poanestezinès priežiūros, intensyviosios terapijos ir intensyviosios priežiūros paslaugas.

\section{Poanestezinė priežiūra}

Remiantis poanestezinès priežiūros kokybės bei saugumo gairèmis [2], tai - stebėsenos ir priežiūros, profilaktikos bei gydymo priemonių visuma, kurios pagrindinis tikslas - užtikrinti pacientų saugumą ankstyvuoju poanesteziniu laikotarpiu (po anestezijos, sedacijos), ịskaitant ankstyvų komplikacijų atpažinimą bei skubų jų gydymą, siekiant išvengti nepageidaujamų baigčių.

Pacientu priežiūra. Galima išskirti svarbiausius personalo priežiūros reikalaujančius dalykus: 1 . Kvèpavimo funkcija: svarbu stebèti pilnaverti kvèpavimo funkcijos atsistatymą, kvėpavimo dažnį, deguonies saturaciją, užtikrinti atvirus kvejpavimo takus. 2. Širdies ir kraujagyslių sistema: širdies susitraukimų dažnio, kraujo spaudimo bei EKG stebėsena gali apsaugoti arba sumažinti kardiovaskulinių komplikacijų dažnį poanesteziniu/pooperaciniu laikotarpiu. 3. Sąmonè: jos stebejjimas ir vertinimas gali aptikti ankstyvąsias komplikacijas bei sumažinti vèlesniujjų dažnį. 4. Skausmas ir pykinimas/vėmimas: svarbi adekvati ankstyva pooperacinio skausmo bei pykinimo/vėmimo kontrole, skiriant farmakologinius preparatus (analgetikai, antiemetikai). 5. Adekvatus skysčiu balanso palaikymas: volemijos vertinimas ir korekcija, diurezès stebejjimas, pooperacinių drenų priežiūra bei skysčių netekimo per juos stebėsena, esant reikalui - transfuzijų atlikimas. 6. Neuroraumeninès jungties funkcijos stebèsena: fizinis ištyrimas bei stebejjimas (pacientams, kuriems anestezijos metu buvo skirti raumenų relaksantai).

Išdèstymas. Poanestezinès priežiūros skyrius (PAPS) 
- tai vieta, ịrengta kiek įmanoma arčiau operacinių bloko, siekiant sutrumpinti pacientu pervežimo iš jo (arba esant reikalui i ji) laiką, aprūpinta kvalifikuotu personalu bei įranga, reikalinga prižiūrèti ir gydyti pacientus ankstyvuoju poanesteziniu ir pooperaciniu laikotarpiu, kol bus nuspręsta juos iškelti ị bendrąsias palatas, kitus ligoninès skyrius, išrašyti i namus [3]. Norint išvengti nepatogumų priežiūros (arba skubių situacijų) metu, PAPS turètų būti pakankamai atviras, be nereikalingų pertvarų, o pacientai gerai matomi medicinos personalui.Trukme. Paslaugos PAPS laikas ribotas. Pacientas po anestezijos stebimas ir gydomas, kol atitinka iškèlimo kriterijus, kurie yra reglamentuoti kiekvienoje klinikoje, tačiau ne ilgiau kaip 24 val. (esant specialiems poreikiams, gali būti daromos išimtys). Atliktos studijos duomenimis, vidutinis PAPS praleistas laikas yra $95 \pm 43 \mathrm{~min}$. ir priklauso nuo pasirinkto anestetiko, anestezijos metodo, infuzoterapijos operacijos metu. Vidutinis

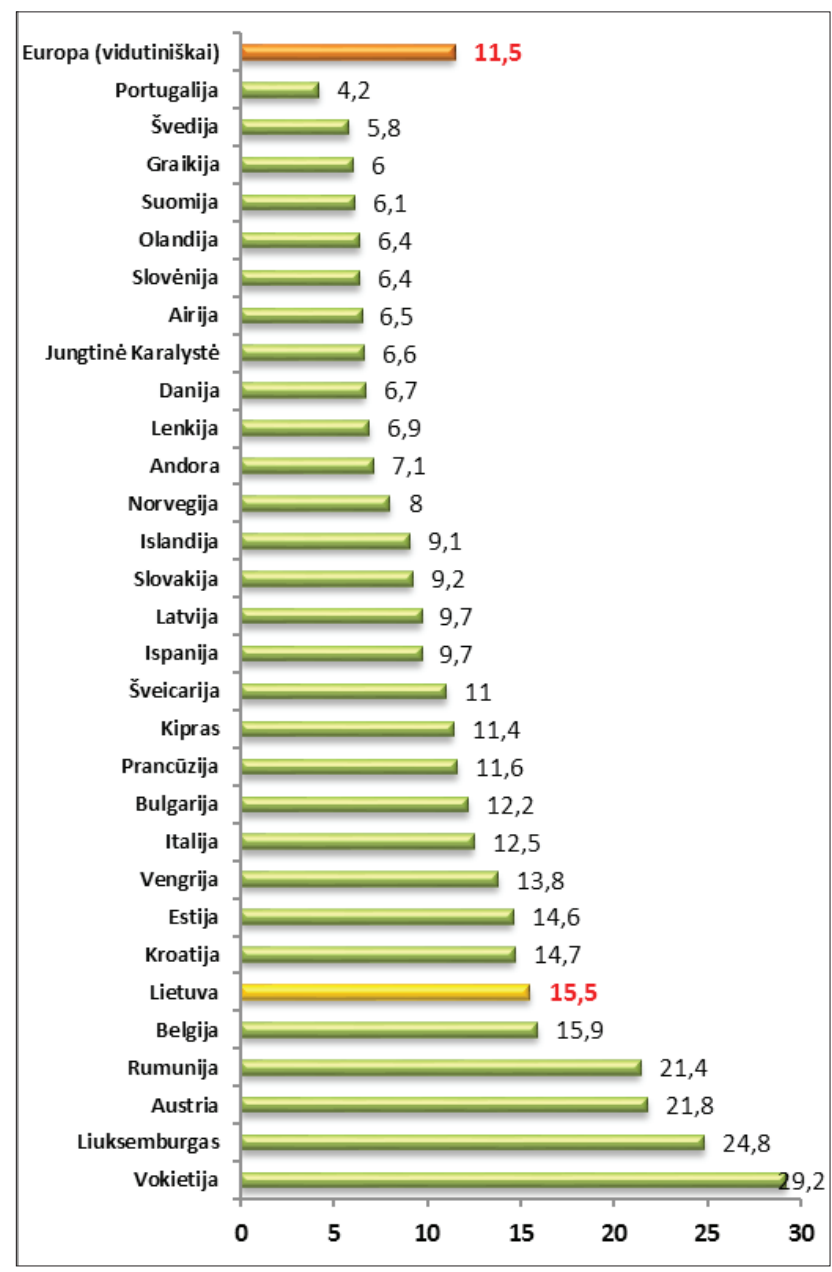

1 pav. Intensyviosios terapijos lovų skaičius Europos valstybėse laikas skyrèsi $>30$ min. nuo laiko, kuris buvo reikalingas PAPS gydytiems pacientams. Laiko skirtumą lèmé radiologinių bei laboratorinių tyrimų atsakymų laukimas [4]. Personalas. Dirbančio personalo kiekis priklauso nuo ligoninès ir paties PAPS profilio. Pacientai turi būti nuolat stebimi specialiai paruoštų slaugytojų. Paprastai - dvi slaugytojos esant bent vienam pacientui. Jeigu pacientai $\mathfrak{i}$ PAPS patenka budrūs ar lengvai pažadinami, slaugytojų/ lovų santykis gali būti sumažintas iki 1:4. Taip pat turi būti bent vienas gydytojas anesteziologas, lengvai pasiekamas ir galintis nedelsiant atvykti ị PAPS [5]. Norint užtikrinti teikiamų paslaugų kokybę, personalas turi būti nuolat mokomas. Todèl siekiant standartų atitikimo, būtina pastoviai atnaujinti gaivinimo igūdžius, diegti technines naujoves, įdiegti naujus skausmo gydymo metodus.

\section{Intensyvioji terapija}

Intensyvioji terapija - sąlyginai jauna medicinos šaka, palyginus su kitomis sritimis, tačiau tapusi neatsiejama visų modernių ligoninių dalimi, kuriai šiuo metu skiriama didelè dalis visos ligoninès biudžeto [1]. Intensyviosios terapijos skyrius (ITS) teikia sveikatos priežiūros paslaugas esant gyvybei grèsmingoms ar galimai gyvybei grèsmingoms pacientų būklèms, esant grịžtamam ar galimai grịžtamam daugybiniam organų nepakankamumui. Šios būklès reikalauja nuolatinès paciento priežiūros bei stebėsenos, skubios diagnostikos bei kompleksinio palaikomojo gydymo.

Pagrindiniai patekimo i ITS kriterijai: 1) kvèpavimo funkcijos nepakankamumas, reikalaujantis invazinès dirbtinès plaučių ventiliacijos; 2) kvėpavimo funkcijos nepakankamumas, nereikalaujantis pakaitinès terapijos, kartu su 2 ar daugiau organų sistemų nepakankamumu; 3) vazoaktyvių medikamentų skyrimas arteriniam kraujo spaudimui palaikyti arba intraaortinè balioninè kontrapulsacija; 4) pacientai po kardiopulmoninio gaivinimo; 5) pakaitinè inkstų terapija ūmaus inkstų nepakankamumo atveju arba kartu su kitų organų nepakankamumu; 6) pacientai, patyrę negrižtamą galvos smegenų pažeidimą, atitinkantys organų donoro kriterijus [6].

Intensyviosios terapijos ypatumai: užtikrinama nuolatinè būklès stebèsena, diagnostiniai tyrimai prie paciento lovos (ang. point of care diagnostics), kombinuota pakaitinè organų terapija, multidisciplininès komandos priežiūra, invazinès gyvybinių funkcijų palaikymo priemonès $[7,8]$.

\section{Intensyviosios priežiūros paslauga}

1. Kodèl reikalinga intensyviosios priežiūros paslauga? Visiems suprantama, kad kritinès būklès pacientas turi būti gydomas intensyviosios terapijos skyriuje. Problema iškyla tada, kai paciento sveikatos būklè nereikalauja in- 
tensyviosios terapijos paslaugu $[1,8]$, bet gydytis skyriaus palatoje būtų pernelyg nesaugu ir rizikinga. Esant ribotam vietų ir personalo skaičiui ITS, tokie pacientai grąžinami ị skyriaus palatas, iš kurių dažnai sugrižta būklei paūmejjus dèl nepakankamai užtikrinamo stebejjimo ir slaugos [10]. Irodyta, kad paciento pakartotinis patekimas i ITS ilgina hospitalizacijos laiką, turi įtakos blogesnems baigtims ir kelia papildomą stresą ITS personalui $[1,12]$. Kita vertus, daug pacientų yra gydomi ITS ilgiau, nei reikètų vien dèl to, kad ligonineje nèra tarpinio lygio sveikatos priežiūros grandies tarp ITS ir paprastos skyriaus palatos [6]. Remiantis Rhodes ir bendraautoriais [11], Lietuva ITS lovų skaičiumi lenkia daugelį Europos valstybių (1 pav).

Studijomis įrodyta, kad didelè dalis ITS gydomų pacientų gali būti sékmingai gydomi ne tokiomis intensyviomis sąlygomis [13]. ITS gydomi pacientai ne visada reikalauja intensyviosios terapijos, pvz., būklès stebejimas trombolizès atlikimo metu ịvykus išeminiam galvos smegenų insultui, diabetinès ketoacidozès (DKA) gydymas. Anot Hayley ir bendraautorių, DKA yra lengvai diagnozuojama būklè, kurios gydymas dažnai prasideda ir baigiasi ITS, tačiau tai nèra būtina. Ypač atsižvelgiant ị tai, jog nẻra specialių gairių, nurodančių, kad šiems pacientams yra būtina intensyvioji terapija. Studijos duomenimis, tik 52,6 proc. iš visų pacientų, kuriems išsivystė DKA, buvo hospitalizuoti i ITS [14].Intensyviosios priežiūros paslauga reikalinga ir pacientams po sunkių operacijų, kurių būklè reikalauja intensyvaus stebèjimo, slaugos ir priežiūros, tačiau jie negali būti gydomi poanestezinejje palatoje ilgiau nei parą. Dèl šios priežasties intensyviosios priežiūros paslaugos susikūrimas yra inicijuojamas anesteziologų, kurie nesiryžta i skyriaus palatas grąžinti komplikuotų pooperacinių pacientų, reikalaujančių intensyvaus stebejjimo, infuzoterapijos ir analgezijos, tačiau taip pat susilaiko nuo jų perkèlimo ị ITS [13]. Iškilus tarpinès grandies tarp skyriaus palatos ir ITS poreikiui, buvo suformuota atskira intensyviosios priežiūros paslaugos koncepcija.

2. Intensyviosios priežiūros paslaugos pradžia. Intensyviosios priežiūros skyriaus (IPS) koncepcija buvo pradèta vystyti dar 1991 metais Didžiojoje Britanijoje. Didžiosios Britanijos ir Airijos anesteziologų asociacija iškèlè progresyviosios priežiūros idèją, pagal kurią pacientai suskirstomi i grupes pagal reikalingą priežiūros lygị ir susirgimo sunkumą. Šiuo metu literatūroje galima sutikti įvairių IPS apibrèžimų. Didžiosios Britanijos ir Airijos anesteziologų asociacija IPS apibrezžia kaip skyrių, kuriame gydomi pacientai reikalauja aukštesnio lygio stebejjimo, gydymo ir slaugos nei galima užtikrinti paprasto skyriaus palatoje. Pacientai, reikalaujantys dirbtinès plaučių ventiliacijos (DPV), nebūtų gydomi IPS, tačiau būtų teikiama invazinio stebejjimo paslauga [15].

Intensyviosios priežiūros paslaugos atsiradimui ir sparčiam paplitimui ịtakos turèjo ir finansiniai aspektai. Šalyse, kuriose buvo atlikti tyrimai (Australija, Naujoji Zelandija, JAV, Didžioji Britanija), pacientų gydymo kaštai IPS ir ITS skyrèsi daugiau nei dvigubai [16-19]. Fox ir kolegų atlikto tyrimo duomenimis, įsteigus IPS, sumažèjo ITS lovų poreikis, taip pat statistiškai reikšmingai sumažèjo ne kritinių būklių pacientų laikas, praleistas ITS. Ligonių skaičius, kuriems buvo reikalingas pakartotinis gydymas ITS taip pat buvo reikšmingai mažesnis [20]. Teikiant siauresnio profilio gydymo, slaugos ir stebejimo paslaugas IPS, sutaupoma ITS lèšu, kurios gali būti sẻkmingai panaudotos kritinių būklių pacientų gydymui.

3. Ypatumai, pacientu kontingentas, tikslai, kriterijai. Pagal lietuvišką apibrèžimą, intensyviosios priežiūros paslauga apibūdinama kaip specialiai įkurtuose ir aprūpintuose reikiama ịranga intensyviosios priežiūros poskyriuose teikiamas siauresnio spektro nei intensyviosios terapijos skyriuose stebejjimas, gydymas ir slauga, kurie negalètụ būti suteikti ir užtikrinti stacionaro skyriu palatose (2 lentelè) [9]. Rekomenduojama, kad atskiros intensyvio-

\section{1 lentelè}

\begin{tabular}{|c|c|}
\hline Nr. & $\begin{array}{c}\text { Intensyviosios priežiūros paslaugos } \\
\text { pacientų kriterijai }\end{array}$ \\
\hline 1. & Deguonies frakcija ịkvėpiamame ore $>50 \%$. \\
\hline 2. & $\begin{array}{l}\text { Reikalingas vienos „sistemos“ (gyvybinès funkcijos) } \\
\text { palaikymas (neinvazinė ventiliacija (NPPV); hemodi- } \\
\text { namikos nestabilumas dèl hipovolemijos, hemoragi- } \\
\text { jos, sepsio ar kitų priežasčių). }\end{array}$ \\
\hline 3. & $\begin{array}{l}\text { Nereikalingos invazinès gyvybinių funkcijų palaiky- } \\
\text { mo priemonės }\end{array}$ \\
\hline 4. & $\begin{array}{l}\text { Centrinès nervų sistemos patologija, kuri gali sąlygoti } \\
\text { apsauginių refleksų išnykimą ar atvirų kvèpavimo takų } \\
\text { palaikymo problemas. }\end{array}$ \\
\hline 5. & $\begin{array}{l}\text { Sutrikusi inkstų funkcija (jei neindikuotina PIT), elek- } \\
\text { trolitų disbalansas, homeostazès sutrikimas. }\end{array}$ \\
\hline 6. & $\begin{array}{l}\text { Išplèstinès pooperacinès priežiūros poreikis po didžių- } \\
\text { jų operacijų, komplikuotos pooperacinès eigos pacien- } \\
\text { tai. }\end{array}$ \\
\hline 7. & $\begin{array}{l}\text { Pacientai, kuriems reikalingas intensyvus stebejimas } \\
\text { išrašius iš intensyviosios terapijos skyriaus, kai yra ne- } \\
\text { saugu juos perkelti ị paprasto skyriaus palatą. }\end{array}$ \\
\hline 8. & $\begin{array}{l}\text { Pacientai, patyrę traumą, kuriems neindikuotinas gy- } \\
\text { dymas intensyviosios terapijos skyriuje. }\end{array}$ \\
\hline 9. & $\begin{array}{l}\text { Stabilių gyvybinių funkciju pacientai, reikalaujantys } \\
\text { nuolatinio medikamento skyrimo automatine švirkšti- } \\
\text { ne pompa (pvz. alteplazè, natrio nitroprusidas ir kt.) }\end{array}$ \\
\hline 10. & $\begin{array}{l}\text { Taikoma tiek chirurginio, tiek terapinio profilio paci- } \\
\text { entams. }\end{array}$ \\
\hline
\end{tabular}


sios priežiūros paslaugos būtų teikiamos skirtingo profilio pacientams - neurochirurginiams, kardiochirurginiams, terapiniams pacientams su kvėpavimo funkcijos nepakankamumu ir pan., tačiau pasaulyje dažniausiai sutinkamas multidisciplininis IPS [13]. Plètojant IPS ideją daug klausimų kèle kriterijai, kuriais vadovaujantis pacientai būtų priimami i IPS ir iš jo išrašomi. Ivvairiose šalyse, kuriose teikiama intensyviosios priežiūros paslauga, kriterijai varijuoja nuo liberalesnių iki griežtesnių $[8,9,21]$. Dažniausi kriterijai, pagal kuriuos sprendžiama, ar pacientas yra tinkamas gydymui IPS, pateikiami 1 lentelèje.
Pagrindinis IPS skirtumas nuo ITS: intensyvesnè pagalba teikiama esant vienos organų sistemos funkcijos sutrikimui, kuomet nereikalingas invazinis gyvybinių funkcijų stebejjimas ar palaikymas. Remiantis kitų šalių praktika, nemažą dali sudaro pacientai, reikalaujantys intensyvesnès slaugos, kuriai užtikrinti skyriaus palatose nèra galimybių, tačiau daugiau nei puse - komplikuotos pooperacinès eigos pacientai, reikalaujantys ne tik intensyvios slaugos, bet ir nuolatinio stebejjimo, infuzoterapijos, analgezijos. Dèl šios priežasties gydytojas anesteziologas yra neatsiejamas nuo sėkmingos IPS veiklos.Iš IPS pacientai iškeliami ị bendrą-

\section{2 lentelè}

Poanestezinès priežiūros paslauga (PAPS) Apibrèžimas: stebėsenos, profilaktikos bei gydymo priemonių visuma, skirta užtikrinti saugų pacientų atsigavimą pooperaciniu laikotarpiu (po anestezijos), i̦skaitant ankstyvų komplikacijų atpažinimą bei skubų jų gydymą, siekiant išvengti nepageidaujamu išeičių.

Ypatumai: ribotas paslaugos laikas - pacientas stebimas po anestezijos kol atitinka iškèlimo kriterijus, bet ne ilgiau kaip 24 val.

Kriterijai (siekiami tikslai):

- Pilnaverčio kvėpavimo funkcijos atsistatymo monitoravimas (kvėpavimo takų praeinamumas, kvėpavimo dažnis, oksigenacija).

- Hemodinamikos stebėsena (kraujospūdis, pulso dažnis, EKG) bei optimizavimas.

- Sąmonès stebejjimas ir vertinimas.

- $\quad$ Adekvati ankstyva pooperacinio skausmo bei pykinimo/vėmimo kontrolè (analgetikai, antiemetikai).

- Adekvataus skysčių balanso palaikymas (volemijos korekcija, diurezès stebėjimas, pooperacinių drenų priežiūra bei skysčių netekimo per juos stebėsena, transfuziju atlikimas)

- Neuroraumeninès jungties funkcijos stebėsena: fizinis ištyrimas bei monitoravimas (pacientams, kurie anestezijos metu buvo skirti nedepoliarizuojantys miorelaksantai).

Iškẻlimo ị profilinị chirurgijos skyrių kriterijai: (Aldrete skalè)

- Visiškai sąmoningi pacientai.

- Kvėpavimo funkcija: pilnavertiškai bei spontaniškai kvėpuojantys (nėra kvėpavimo takų obstrukcijos ar KFN atsistatę apsauginiai kvėpavimo takų refleksai); kvėpavimo funkcija bei kraujo įsotinimas deguonimi pasiekę priešoperacinį/priešanestezinị lygit.

- Stabili hemodinamika.

- Nèra neaiškių pažeidimų ar nekontroliuojamo kraujavimo.

- Kontroliuojamas skausmas bei pykinimas/vèmimas (analgetikai, antiemetikai).

- Jei yra abejoniu dèl paciento būklès pagerèjimo bei atitikimo iškèlimo iš poanestezinès priežiūros palatos kriterijams, toks pacientas turètų büti perkeliamas ị intensyviosios priežiūros paslauga teikiančia palatą (IPS) arba $i$ intensyviosios terapijos skyriu (ITS) tolimesniam stebejjimui bei gydymui.

- Taikoma chirurginio profilio pacientams.
Intensyviosios priežiūros paslauga (IPS) Apibrèžimas: specialiai ịkurtuose ir aprūpintuose reikiama įranga intensyviosios priežiūros poskyriuose teikiamas siauresnio spektro nei intensyviosios terapijos skyriuose stebejjimas, gydymas ir slauga, kurie negalètu būti suteikti ir užtikrinti stacionaro skyrių palatose.

Ypatumai:

- Intensyvus pacientų stebèjimas.

- Pastovus monitoravimas.

- Gydymas ir slauga.

\section{Kriterijai (siekiami tikslai):}

- Deguonies poreikis ikvejpiamame ore daugiau, nei $50 \%$.

- Reikalingas vienos „sistemos“ (gyvybinès funkcijos) palaikymas (neinvazinè ventiliacija (NPPV); hemodinamikos nestabilumas dèl hipovolemijos, hemoragijos, sepsio ar kitų priežasčių).

- Nereikalingos invazinės gyvybinių funkcijų palaikymo priemonès.

- Centrinès nervų sistemos patologija, kuri gali sąlygoti apsauginiu refleksu išnykima ar atvirų kvẻpavimo takų palaikymo problemas.

- Sutrikusi inkstų funkcija (jei neindikuotina PIT), elektrolitų disbalansas, homeostazès sutrikimas.

- Išplèstinès pooperacinès priežiūros poreikis po didžiujų operacijų, komplikuotos pooperacinès eigos pacientai.

- Pacientai, kuriems reikalingas intensyvus stebèjimas išrašius iš intensyviosios terapijos skyriaus, kai yra nesaugu juos perkelti ì paprasto skyriaus palatą.

- Pacientai, patyrę traumą, kuriems neindikuotinas gydymas intensyviosios terapijos skyriuje.

- Stabilių gyvybinių funkcijų pacientai, reikalaujantys nuolatinio medikamento skyrimo AŠP (pvz. alteplazè, natrio nitroprusidas ir kt.) - Taikoma tiek chirurginio, tiek terapinio profilio pacientams.
Intensyviosios terapijos paslauga (ITS) Apibrèžimas: intensyviosios terapijos skyrius teikia sveikatos priežiūros paslaugas esant gyvybei grèsmingoms, ar galimai gyvybei grèsmingoms pacientų būklèms, esant grịžtamam ar galimai grịžtamam daugybiniam organų nepakankamumui.

Ypatumai:

- Nuolatinis būklès monitoravimas.

- Diagnostiniai tyrimai prie paciento lovos.

- Kombinuota pakaitiné organų terapija.

- Multidisciplininès komandos priežiūra.

- Invazinès gyvybinių funkcijų palaikymo priemonés.

\section{Kriterijai (siekiami tikslai):}

- Kvėpavimo funkcijos nepakankamumas, reikalaujantis invazinès dirbtinès plaučių ventiliacijos

- Kvèpavimo funkcijos nepakankamumas, nereikalaujantis pakaitinès terapijos, kartu su 2 ar daugiau organų sistemų nepakankamumu.

- Vazoaktyvių medikamentų skyrimas arteriniam kraujo spaudimui palaikyti arba intraaortiné balioninè kontrapulsacija.

- Pacientai, po kardiopulmoninio gaivinimo.

- Pakaitiné inkstų terapija ūmaus inkstų nepakankamumo atveju arba kartu su kitų organų nepakankamumu.

- Pacientai, patyrę negrižtamą galvos smegenų pažeidimą, atitinkantys organų donoro kriterijus. 
sias palatas, kai būklè stabilizuojasi ir intensyvi slauga ar gyvybinių funkcijų palaikymas tampa neindikuotinas, arba i ITS, jei išryškejja intensyvios priežiūros, DPV poreikis ar organų funkcijos nepakankamumas, apimantis daugiau nei vieną organų sistemą. Tam tikra prasme, IPS gali tarnauti kaip buferine zona tarp ITS ir skyriaus palatos [1]. Taip pat dažnai IPS atstoja ITS esant vietų trūkumui dẻl kritinių būkliu pacientų gausos. Pagal mažesnių pasaulio ligoninių praktiką, galimas IPS prijungimas prie ITS, paskiriant atitinkamą lovų skaičių intensyviosios priežiūros paslaugai. Tai leidžia efektyviau panaudoti ligoninès išteklius ir paskirstyti personalą, taip pat, esant poreikiui, IPS lovos gali būti paskiriamos intensyviosios terapijos pacientams. Sprendimus apie priimamus ir išrašomus pacientus priima IPS dirbantis gydytojas ar jo prižiūrimas gydytojas rezidentas [9]. Vadovaujantis IPS koncepcija, pacientai turètų būti gydomi ir stebimi ne ilgiau kaip 48 val., tačiau remiantis pasaulio praktika, intensyviosios priežiūros paslauga gali būti teikiama ir ilgiau $[8,13]$.

4. Darbo organizavimas. Nèra vienos universalios intensyviosios priežiūros teikimo paslaugos koncepcijos, dèl to kiekviena ligoninè, teikianti šią paslaugą, reglamentuoja savo taisykles, pagal kurias organizuojamas darbas IPS. Teikiant multidisciplinines stebejimo, gydymo ir slaugos paslaugas dažnai iškyla klausimas, kas turètų būti atsakingas už darbą IPS ir jame gydomus pacientus. Gydantis gydytojas, operavęs chirurgas, anesteziologas reanimatologas, o gal ITS personalas? Literatūros šaltiniuose pateikiami keli galimi variantai [13]:

1. IPS gydomais pacientais rūpinasi juos skyriuje gydę gydytojai arba operavę chirurgai. Šio modelio privalumas tas, kad gydantys gydytojai yra įtraukiami ị tolimesni gydymo procesą ir geriau pažindami savo pacientus gali sèkmingiau juos gydyti. Kita vertus, dèl laiko stokos, ilgų valandų, praleidžiamų operacinèje ar skyriuje, gali būti sunku IPS gydomiems pacientams skirti reikalingą dèmesio kiekị ir laiku reaguoti ị reikšmingus būklès pokyčius. Dèl šios priežasties toks darbo organizavimo modelis labiau tinka specializuotiems IPS, pvz., kardiochirurgijos ar neurochirurgijos IPS [8].

2. Antrasis darbo organizavimo modelis reglamentuoja, kad IPS gydomais pacientais rūpinasi ITS personalas. Dirba patyrę gydytojai ir slaugytojos, pacientams teikiama kvalifikuota pagalba ir taip jie yra apsaugomi nuo patirties neturinčių specialistų sprendimų, tačiau tokiu atveju gydantys skyriaus gydytojai mažiau įtraukiami į gydymo procesą.3. Kombinuota priežiūra, kai gydę skyriaus gydytojai ar operavę chirurgai tęsia gydymą kartu su anesteziologais ir kitais specialistais, tačiau intensyviu stebėjimu, slauga ir gyvybinių funkcijų užtikrinimu, homeostazès korekcija rūpinasi ITS personalas. Manoma, kad toks darbo organizavimo modelis geriausiai atitinka IPS keliamus tikslus, tačiau dirbant kelioms komandoms vienu metu ypač svarbi tampa komunikacijos ir teisinès atsakomybès už priimtus sprendimus problema.Remiantis australų patirtimi, pacientų gydymas, stebejjimas ir slauga geriausiai užtikrinami vadovaujantis trečiuoju darbo organizavimo modeliu. Nèra tiksliu rekomendacijų, kiek gydytojų turètų dirbti IPS. Hasin ir kolegu pateikiamais duomenimis apie darbo organizavimą kardiologijos IPS, vienam gydytojui tenka po 6-8 pacientus, priklausomai nuo IPS dydžio [8]. Darbo taisyklès ir instrukcijos, personalo kiekis ir sudètis, pacientu perkèlimo ir iškèlimo kriterijai turi būti reglamentuojami pačios ligoninès nuostatomis.

IPS rekomenduojamas slaugytojų ir pacientų santykis yra 1:2-1:4, kai tuo tarpu ITS rekomenduojamas santykis yra 1:1 [9]. Garfield ir kolegų atliktos studijos duomenimis, slaugytojų ir pacientų santykis 1:2 nèra pakankamas, dèl tojų rekomenduojamas santykis yra 2:3 [22]. IPS dirbančios slaugytojos turètų būti specialiai apmokytos ir akredituotos [8].

5. Rekomendacijos aprūpinimui ir išdestymui. Siekiant visiškai užtikrinti ir kokybiškai teikti intensyviosios priežiūros paslaugą, reikalinga sukurti tinkamą infrastruktūrą, todèl literatūroje galima sutikti pateikiamas rekomendacijas apie IPS išdėstymą ir aprūpinimą reikiama ịranga [23]. Ivertinus IPS tikslus ir gydomų pacientų kontingentą rekomenduojama, kad intensyviosios priežiūros paslauga būtų teikiama šalia ITS. Taip užtikrinamas efektyvesnis ligoninès išteklių ir ITS personalo paskirstymas, IPS ir ITS bendradarbiavimas, įrangos ir medikamentu dalinimasis $[1,8]$. Taip pat, žinant, kad daugiau nei pusè pacientų, kuriems reikalinga intensyviosios priežiūros paslauga, yra komplikuotos pooperacinès eigos pacientai po sudètingu ịvairaus profilio operacijų, rekomenduojama, kad IPS būtų ịkurtas šalia operacinio bloko. Tai užtikrintu greitas ir lengvai prieinamas gydytojo anesteziologo paslaugas 24 valandas per parą.IPS turètų būti suprojektuotas taip, kad visi pacientai būtų matomi iš gydytojų ir slaugytojų stebejimo posto, kuris būtų pakankamai erdvus, kad būtų sukurtos optimalios darbo sąlygos [8].Australų pateikiamose rekomendacijose nurodomas IPS lovų skaičius yra 1,7-2,1/100 ligoninès lovų, tačiau šis skaičius gali kisti priklausomai nuo ligoninės dydžio, profilio ir atliekamų procedūrų pobūdžio [13], tuo tarpu kardiologijos IPS rekomenduojamas lovų santykis ITS:IPS yra 1:3 [8]. Vienai lovai turètų būti skiriama apie 16-20 $\mathrm{m}^{2}$ ploto [23]. Kiekviena IPS vieta turètų būti aprūpinta standartine stebėsenos ịranga - kardiomonitorius, EKG registravimas, pulsoksimetras, neinvazinis AKS stebejimas, siurbimo ịranga ir elektros prieiga [23]. Pacientams dažnai keičiant savo gydymo vietą, turètų 
būti pasirūpinta gyvybinių funkcijų stebejjimo ir palaikymo įranga transportavimo metu [8, 13, 23]. Aprūpinimas ir skyriaus išdėstymas priklauso nuo kiekvienos ligoninès galimybių ir IPS profilio bei pacientų kontingento.

\section{Išvados}

Aprašytos pacientų gydymo, stebejjimo ir slaugos paslaugos yra neatsiejamos nuo pilnavertiškai funkcionuojančios ligoninès veiklos. Poanestezinè priežiūra ir intensyvioji terapija sèkmingai gyvuoja jau kelis dešimtmečius, tuo tarpu pasaulio ligoninèse pripažinta intensyviosios priežiūros paslauga Lietuvoje dar tik žengia pirmuosius žingsnius. Nekyla abejonių, kad IPS būtinas siekiant užtikrinti saugias ir maksimaliai efektyvias sveikatos priežiūros paslaugas. Esant tarpinei grandžiai tarp ITS ir skyriaus palatos, pacientams suteikiama jų būklę atitinkanti sveikatos priežiūra, nes išvengiama rizikos, susijusios su nepakankama priežiūra skyriaus palatoje, taip pat pacientams netenka gydytis papildomą stresą keliančiomis, triukšmingomis ITS sąlygomis [9]. Svarbu ir tai, kad tokiu būdu sumažèja pacientų gydymui skiriami kaštai.

\section{Literatūra}

1. Vincent JL, Rubenfeld GD. Does intermediate care improve patient outcomes or reduce costs? Critical Care (2015) 19:89.

http://dx.doi.org/10.1186/s13054-015-0813-0

2. Vimlati L, Gilsanz F, Goldik Z. Quality and safety guidelines of postanaesthesia care, Working Party on Post Anaesthesia Care (approved by the European Board and Section of Anaesthesiology, Union Européenne des Médecins Spécialistes). European Journal of Anaesthesiology 2009, 26:715-721.

http://dx.doi.org/10.1097/EJA.0b013e32832bb68f

3. Standards for postanesthesia care. Committee of Origin: Standards and Practice Parameters. Approved by the ASA House of Delegates on October 27, 2004, and last amended on October 15, 2014. Prieiga per internetą: http://www.asahq.org/qualityand-practice-management/standards-and-guidelines.

4. Waddle JP, Evers AS, Piccirillo JF. Postanesthesia care unit length of stay: quantifying and assessing dependent factors. Anesth Analg 1998 Sep;87(3):628-33.

5. Apfelbaum JL, Silverstein JH, Chung FF, Connis RT, Fillmore RB. et al. Practice guidelines for postanesthetic care: an updated report by the American Society of Anesthesiologists Task Force on Postanesthetic Care. Anesthesiology 2013;118(2):291-307. http://dx.doi.org/10.1097/ALN.0b013e31827773e9

6. Guidelines on admission to and discharge from intensive care and high dependency units. Department of health, $1996 \mathrm{~m}$. NHS executive.

7. Valentin A, Ferdinande P. et al. Recommendations on basic requirements for intensive care units: structural and organizational aspects. Intensive Care Medicine, 2011;37(10):1575-87. http://dx.doi.org/10.1007/s00134-011-2300-7

8. Hasin Y, Danchin N, Filippatos G, Heras M, Janssens U. et al. Recommendations for the structure, organization, and operation of intensive cardiac care units. European Heart Journal,2005;26(16):1676-82.

http://dx.doi.org/10.1093/eurheartj/ehi202

9. Nasraway SA, Cohen IL, Dennis RC, Howenstein MA, Nikas DK. et al. Guidelines on Admission and Discharge for Adult Intermediate Care Units. Crit Care Med 1998;26:607-610. http://dx.doi.org/10.1097/00003246-199803000-00039

10. Byrick RJ, Mazer CD, Caskenette GM. Closure of an intermediate care unit. Impact on critical care utilization. Chest 1993; 104(3):876-81.

http://dx.doi.org/10.1378/chest.104.3.876

11. Rhodes A, Ferdinande P, Flaatten H, Guidet B, Metnitz PG. et al. The variability of critical care bed numbers in Europe. Intensive Care Medicine 2012; 38(10):1647-53.

http://dx.doi.org/10.1007/s00134-012-2627-8

12. Rosenberg AL, Hofer TP, Hayward RA, Strachan C, Watts CM. Who bounces back? Physiologic and other predictors of intensive care unit readmission. Crit Care Med 2001; 29(3):511-8. http://dx.doi.org/10.1097/00003246-200103000-00008

13. Fficanzca J. The High Dependency Unit: Role and Management. Australasian anaesthesia. 1998. Prieiga per internetą: http://web.squ.edu.om/med-lib/med_cd/e_cds/health\%20development/html/clients/WAWFSA/html/papers/pap015.htm\#intr

14. Gershengorn HB, Iwashyna TJ, Cooke CR, Scales DC, Kahn $\mathrm{JM}$ et al. Variation in use of intensive care for adults with diabetic ketoacidosis. Critical Care Medicine 2012;40(7):2009-15. http://dx.doi.org/10.1097/CCM.0b013e31824e9eae

15. Association of Anaesthetists of Great Britain and Ireland (1991) The high dependency unit - acute care in the future. (Association of Anaesthetists of Great Britain and Ireland,London).

16. Crosby DL, Gill J, Rees GA. The role of the high dependency unit in postoperative care: an update. Ann R Coll Surg Eng 1990; 72(5):309-12.

17. Popovich J Jr. Intermediate care units. Graded care options. Chest 1991; 99(1):4-5.

http://dx.doi.org/10.1378/chest.99.1.4

18. Elpern E, Silver MR, Rosen RL, Bone RC. The noninvasive respiratory care unit. Patterns of use and financial implications. Chest 1991; 99(1):205-8.

http://dx.doi.org/10.1378/chest.99.1.205

19. Douglas S, Daly B, Rudy E, Song R, Dyer MA. et al. The costeffectiveness of a special care unit to care for the chronically critically ill. J Nursing Administration 1995; 25(11):47-53. http://dx.doi.org/10.1097/00005110-199511000-00009

20. Fox A J, Owen-Smith O, Spiers P. The immediate impact of opening an adult high dependency unit on intensive care unit occupancy. Anaesthesia 1999; 54:266-296. http://dx.doi.org/10.1046/j.1365-2044.1999.00715.x 
21. Leeson - Payne CG, Aitkenhead AR. A prospective study to assess the demand for a high dependency unit. Anaesthesia 1995; 50(5):383-7.

http://dx.doi.org/10.1111/j.1365-2044.1995.tb05988.x

22. Garfield M, Jeffrey R, Ridley S. An assessment of the staffing level required for a high-dependency unit. Anaesthesia 2000; 55:137-143.

http://dx.doi.org/10.1046/j.1365-2044.2000.055002137.x

23. Guidelines on standards for high dependency units for training in intensive care medicine. College of Intensive Care Medicine of Australia and New Zealand, 2013. Prieiga per internetą: http://www.cicm.org.au/CICM_Media/CICMSite/ CICM-Website/Resources/Professional\%20Documents/IC13-Guidelines-on-Standards-for-High-Dependency-Units.pdf

\section{POST-ANESTHESIA CARE, INTENSIVE CARE AND} HIGH DEPENDENCY UNIT SERVICES

\section{Traškaitė, D. Urbanaitė, K. Stašaitis, D. Trepenaitis,} A. Macas

Key words: post-anesthesia care, intensive care, high dependency unit services, high dependency unit.
Summary

Post-anesthesia care unit (PACU) and intensive care unit (ICU) provide services in hospitals all over the world and Lithuania as well. However recent situation indicates that ICUs are overloaded with non-ICU patients and various patients after major surgeries often are too weak to be treated in general wards. Considering this situation as an issue, new concept has been found. High dependency unit (HDU) is like buffer zone: ,step down“ from ICU and „step up“ from the general ward. HDU provides services which are adequate for condition of a particular patient. The main aim of this article is to compare and separate services which are provided in postanesthesia, intensive and high dependency care units. The main aims, criteria and organization issues are discussed in this article.

Correspondence to: dalia0220@gmail.com

Gauta 2015-09-29 